\title{
Романкина М.Ю., Мухамеджанова М.А., Иванова Е.Н. Биоиндикация загрязнений атмосферного воздуха по состоянию древесных растений в парках в условиях города Мичуринска Тамбовской области
}

ФГБОУ ВО «Мичуринский государственный аграрный университет» (Россия, Мичуринск)

doi: 10.18411/trnio-11-2021-33

\section{Аннотация}

Актуальность выбранной темы связана с тем, что виды-индикаторы - растения (береза повислая), произрастающие в парках, позволяют выявить специфические особенности среды в связи с антропогенной нагрузкой, что сказывается на условиях обитания организмов и приводит к сокращению биоразнообразия.

Полученные знания будут формировать у обучающихся навыки практического применения теоретических знаний и помогут будущим учителям организовать научноисследовательскую деятельность в школе.

Ключевые слова: среда обитания, урбонизированный ландшафт, угородской парк, береза повислая, морфологическая изменчивость.

\section{Abstract}

The relevance of the chosen topic is due to the fact that indicator species - plants (drooping birch) growing in parks, make it possible to identify specific features of the environment in connection with anthropogenic load, which affects the living conditions of organisms and leads to a decrease in biodiversity.

The knowledge gained will form students' skills in the practical application of theoretical knowledge and will help future teachers to organize research activities at school.

variability.

Keywords: habitat, urbanized landscape, Ugorodsky park, drooping birch, morphological

Среда обитания современного человека - это искусственно-естественная среда. Ее формируют как биологические, так и социальные факторы, которые связаны между собой и взаимообусловлены. Одна из важнейших функций, которую призваны выполнять парки оптимизация состояния городской среды, обеспечение возможно более высокого уровня экологического комфорта. Наличие парков в городах значительно повышает качественные характеристики среды обитания человека. Это происходит в силу того, что парк способствует удовлетворению экологических потребностей. Условно экологические потребности можно разделить на две основные группы: биоэкологические, учитывающие потребности физического существования человека и социоэкологические, характеризующие многофункциональность парков [1-3].

Зеленые насаждения в парках снижают запыленность и загазованность воздуха, выполняют ветрозащитную функцию, борются с шумом, влияют на тепловой режим и влажность воздуха. В городах лишь на территории парков сохраняются относительно обширные не асфальтированные площади. Даже при значительном изменении чисто природных характеристик городской парк в условиях урбанизированного ландшафта является своеобразным «заповедником» [1].

Цель исследования - определение с помощью видов-индикаторов качество атмосферного воздуха в исследуемых парках города Мичуринска Тамбовской области и дать оценку загрязнённости атмосферы методами биоиндикации.

Исследования по изучению загрязнения атмосферы в парках Культуры и отдыха и парка Победы с использованием биоиндикаторов проводились в 2019-2021 гг.. 
Материалом для данной работы послужили наблюдения за состоянием листовых пластинок березы повислой, лишайников, а также подсчёт и анализ транспортного потока для оценки загрязнённости атмосферы.

Изменчивость различных морфологических признаков в условиях антропогенного воздействия часто возрастает. Нарушение симметрии билатеральных органов может отражать неблагополучие окружающей среды $[1 ; 4]$.

Была проведена оценка степени газодымного загрязнения по разнообразию листовых пластинок березы повислой. В исследуемых парках выбрали по 5 деревьев с которых было собрано по 100 штук листьев. Затем определяли форму каждой листовой пластинки с помощью вспомогательной таблицы и изучали морфологическую изменчивость, что дало возможность определения степени газодымного загрязнения атмосферы в модельных районах.

В условиях антропогенного воздействия часто возрастает изменчивость различных морфологических признаков. В незагрязненных районах более $3 / 4$ листьев березы повислой широко-округлые (80\%) (форма I). При загрязнении возрастает разнообразие листьев, особенно формы II (до 45\%).

По результатам исследования в парке Победы типы листовых пластинок берёзы повислой преобладают по численности, за исключением первого типа. Число листьев берёзы этого типа выше в парке Культуры и отдыха, что составило 52 \%. Тогда как в парке Победы широкоокруглые листья у березы составили $45 \%$.

Таким образом, проведенные исследования показали, что состояние атмосферного воздуха в парке Культуры и отдыха лучше, чем в парке Победы.

Методы оценки загрязнённости атмосферы по встречаемости лишайников основаны на следующих закономерностях: чем сильнее загрязнён воздух, тем меньше встречается в нём видов лишайников (вместо десятков может быть один - два вида); чем сильнее загрязнён воздух, тем меньшую площадь покрывают лишайники на стволах деревьев.

В парке Победа с антропогенной нагрузкой видовое разнообразие лишайников не велико. У основания стволов деревьев встречается накипной лишайник. Жизнеспособность лишайников на этих участках низкая, слоевище чахлое. На участке с уменьшенной антропогенной нагрузкой (близкое расположение железной дороги). В парке Культуры и отдыха жизнеспособность лишайников умеренная, но встречаются лишайники с высокой степенью жизнеспособности и здоровым слоевищем.

Таким образом, в своей работе учителю следует уделять особое внимание строгой проверке учебной информации на соответствие ее научным закономерностям, что будет способствовать развитию познавательного интереса к преподносимой информации, формированию научного мировоззрения, повышению научности сообщаемых фактов. Сведения о возможности проведения мониторинговых работ для оценки уровня загрязнения атмосферного воздуха в городских парках повысят актуальность сообщаемых фактов и сформируют мотивацию к изучению учебной информации. Подобного рода работы, несомненно, вызывают большой интерес у обучающихся разных возрастных групп, поэтому должны занять достойное место в работе учителя естественнонаучного образования.

$$
* * *
$$

1. Ашихмина Т.Я. Школьный экологический мониторинг: учебное методическое пособие / Под ред. Т.Я. Ашихминой. М.: Агар. 2000. 385 с.

2. Боев В.А., Боева О.И., Романкина М.Ю. Экологическая направленность внеурочной деятельности по ОБЖ // Наука и образование: научный рецензируемый электронный журнал, 2018 . № $3 . \quad$ URL: http://opus.mgau.ru/index.php/see

3. Карпачева Т.В., Каргальцева А.Р. Изучение вопросов экологической безопасности в педагогической мастерской // Наука и образование. 2019. № 2 URL: http://opusmgau.ru/index.php/see/article/view/999.

4. Фофонова А.С., Романкина М.Ю. Формирование и развитие учебно-познавательной компетентности обучающихся при использовании современных технологий обучения // Наука и образование. 2019. № 2 URL: http://opusmgau.ru/index.php/see/article/view/999. 